(2) The surface water must be of approximately the same salinity as that of the sea bottom; if it has a much lower salinity, its density may not be increased by a reduction of temperature to an extent sufficient to set up convection movements reaching to the sea-bottom. (3) It must be cooled to a slightly lower temperature than that of the water at the sea-bottom, for its adiabatic contraction, by pressure, as it sinks, must warm it slightly; this may be the cause of the slight increase in the temperature of oceanic water as we approach great depths-an increase which has been attributed to the emission of heat by radio-active substances in the oceanic bot'smdeposits. (4) The formation of ice on the seasurface may favour convection currents by raising the salinity of the superficial water; but this is not an important factor.

The cold bottom water of the North Atlantic Ocean originates in a restricted area of sea, outside the boundaries of the southerly-flowing polar current, and lying to the south-east of Greenland. Some of this water may also proceed from the surface of the Norwegian Sea after flowing over the Faröe-Iceland ridge.

Incidentally Dr. Nansen directs attention to the presence of Mediterranean water in the channel between Ireland and Rockall. This originates from warm and dense water flowing out as an intermediate current through the Straits of Gibraltar. The presence of this water in British seas was pointed out by Dickson in Igog as the result of observations made in 1903 by Wolfenden. Dr. Nansen in 1909 referred to the methods of these observations as "so inaccurate as to be of little use." Nevertheless, he now adopts the conclusions drawn from them, without, however, referring to Dickson's prior discovery.

\section{J. J.}

\section{SOUTH AFRICAN INSTITUTE FOR MEDICAL RESEARCH.}

SOUTH AFRICA has decided to have an institute for medical research on the same lines as the Pasteur Institute in Paris, the Lister Institute of Preventive Medicine in London, or the Rockefeller Institute in New York. To this end a new building is now in pror _ss of erection in Johannesburg, and is expectr $A$ to be complete in about twelve months.

A site has been provided by the Government, and we understand that the cost of building and equipping the new institute will be provided by the Witwatersrand Native Labour Association. The maintenance of the institution will be undertaken by the Government of South Africa and the association in equal shares.

A very satisfactory feature of the institute will be its close proximity to the largest hospital in South Africa, with which it is intended that it should work in conjunction. It will also be equipped with four wards for the purpose of treating patients, who will be the subject of special study.

$$
\text { No. } 227 \mathrm{O}, \text { VOL. 9I] }
$$

From the present plans, the institute seems to be suitably arranged, and will be an imposing structure. It will comprise, in a main block, forming a two-storied quadrangle, the institute offices, experimental and observation hospital, animal house, mortuary, and director's house. Ample space is allowed here for future extension. Of this main block the northern and southern sides are prolonged eastwards and westwards to form two further quadrangles. These will contain the hospital wards and research laboratories, also library, museum, and further laboratories. The building will carry as well a lecture theatre, basement workshops and storage rooms, and a number of rooms for miscellaneous scientific purposes. A dome eighty feet in height will crown the building, and will carry a finial emblematic of the surrender by Death of his secret, and we understand that a second dome of equal magnitude is aspired to. Although we realise that an institute which is intended to render valuable service to the State should be housed in fashion suitable to the importance of the work it is to undertake, we sincerely hope that contemplation of the domes and the finial will not distract the attention of the authorities from the fact that the success of their scheme will essentially depend upon the personnel of the staff and the funds made available for scientific investigation.

The research work of the institute is, we understand, to be primarily directed towards the industrial diseases of the Transvaal, but all diseases will come under its scope. It is intended that research fellowships shall be available for medical men, in order that they may carry out special lines of investigation; also it is hoped that in the near future medical students will be enabled to undertake courses in pathology and bacteriology at the institute, of a character which can now only be attended in Europe.

Two appointments to the staff of the institute have already been made : the director of the institute will be Dr. Watkins Pitchford, and the statistician Dr. G. D. Maynard, both of whom have already accomplished sound work in connection with one or other of the public health organisations of the colonies now forming the Dominion of South Africa.

\section{EDUCATION OF THE AUDITORY CENTRES. ${ }^{1}$}

PROF. MARAGE, who is well known as an otologist and for his researches in physiological acoustics, has issued a small but suggestive pamphlet on what he terms the education of the auditory centres. It is known that there are cases in the clinique of the aurist where there is sensitiveness to even feeble noises while there is deafness to music and to speech. In others the patient may hear noises, music, and even speech sounds, but without any understanding of the meaning of the speech sounds. Prof. Marage

1 "Education et Rééducation des Centres auditifs." By Prof. Marage. Pp. 15. (Paris, I9 Rue Cambon.) 